\title{
Pengaruh Corporate Social Responsibility pada Nilai Perusahaan dengan Kinerja Lingkungan Sebagai Pemoderasi
}

\author{
Veronica Padma Lingga ${ }^{1}$ \\ M. G. Wirakusuma ${ }^{2}$ \\ ${ }^{1}$ Fakultas Ekonomi dan Bisnis Universitas Udayana (Unud), Bali, Indonesia \\ E-mail: veronicalingga1@ @mail.com \\ ${ }^{2}$ Fakultas Ekonomi dan Bisnis Universitas Udayana (Unud), Bali, Indonesia
}

\begin{abstract}
ABSTRAK
Penelitian ini bertujuan untuk menetahui pengaruh Corporate Social Responsibilty (CSR) terhadap nilai perusahaan dengan kinerja lingkungan sebagai pemoderasi. Penelitian ini dilakukan pada perusahaan sektor industri dasar dan kimia, aneka industri, dan pertambangan yang terdaftar di Bursa Efek Indonesia periode 2015-2017. Teknik pengambilan sampel dalam penelitian ini diambil berdasarkan metode non-probability sampling dengan teknik purposive sampling sehingga menghasilkan sampel sebanyak 43 perusahaan. Teknik analisis data yang digunakan dalam penelitian ini adalah uji moderated regression analysis. Berdasarkan hasil analisis ditemukan bahwa Corporate Social Responsibilty (CSR) berpengaruh positif pada nilai perusahaan. Hasil penelitian ini juga menunjukkan kinerja lingkungan tidak mampu memoderasi pengaruh Corporate Social Responsibilty $(C S R)$ pada nilai perusahaan, yang dikarenakan kinerja lingkungan yang baik belum tentu dapat memberikan dampak positif atau keuntungan bagi para investor.
\end{abstract}

Kata Kunci: corporate social responsibility, nilai perusahaaan, kinerja lingkungan

\begin{abstract}
This study aims to determine the effect of Corporate Social Responsibility on the value of the company with environmental performance as moderating. This research was conducted on basic industrial and chemical sector companies, various industries, and mining listed on the Indonesia Stock Exchange for the period 2015-2017. The sampling technique in this study was taken based on non-probability sampling method with a purposive sampling technique so as to produce a sample of 43 companies. The data analysis technique used in this study was moderated regression analysis. Based on the results of the analysis it was found that Corporate Social Responsibility had a positive effect on firm value. The results of this study also show that environmental performance is not able to moderate the influence of Corporate Social Responsibility on firm value, which is due to good environmental performance that may not necessarily have a positive impact or benefits for investors.
\end{abstract}

Keywords: corporate social responsibility, corporate value, environmental performance 


\section{PENDAHULUAN}

Seiring dengan perusahaan yang semakin berkembang, maka tingkat kesenjangan sosial dan kerusakan lingkungan semakin tinggi, hal itu terjadi karena adanya aktivitas perusahaan yang tidak terkendali terhadap berbagai sumber daya (Makalew, 2017). Pertumbuhan ekonomi mengalami peningkatan karena adanya kegiatan operasi perusahaan, tetapi di sisi lain perusahaan juga merupakan penyebab terjadinya kerusakan lingkungan (Nahda \& Harjito, 2011).

Pasar percaya bahwa nilai perusahaan yang tinggi bukan hanya karena kinerja perusahaan saat ini, tetapi juga pada prospek perusahaan di masa mendatang (Keown, 2004). Nilai perusahaan adalah persepsi pemegang saham terhadap tingkat keberhasilan perusahaan yang sering dikaitkan dengan harga saham (Sujoko \& Soebiantoro, 2007). Menurut Latupono (2015) semakin bertanggungjawab perusahaan akan lingkungannya, maka citra perusahaan menjadi semakin baik. Apabila perusahaan memiliki citra yang baik dimata masyarakat, maka perusahaan akan dapat meningkatkan loyalitas konsumen terhadap perusahaan, sehingga secara tidak langsung akan meningkatkan nilai perusahaan (Nahda \& Harjito, 2011).

Banyak perusahaan dalam menjalankan usahanya tidak memperhatikan program pengelolaan lingkungan sekitarnya (Makalew, 2017). Contohnya pada tanggal 25 Desember 2017 harga saham INKP ditutup melemah Rp310 (-7.20\%) ke level Rp3.990 hal ini diduga akibat pencemaran lingkungan yang ditimbulkan oleh INKP di Perawang, Kabupaten Siak (http://www.sahamonline.id , 2017). INKP diketahui telah menggunakan bahan klorin, yang sangat berbahaya karena 
mampu membunuh makhluk hidup yang menghirupnya secara perlahan. Hal ini membuktikan bahwa kerusakan lingkungan yang diakibatkan suatu perusahaan yang disengaja atau tidak disengaja membawa dampak yang sama negatif bagi perusahaan tersebut. Semakin kuat sanksi yang diberlakukan maka semakin berkurang adanya penyimpangan (Mobus, 2005).

Menurut Soerjani, dkk. (1987) pengelolaan lingkungan adalah upaya untuk melestarikan lingkungan yang meliputi pengembangan, pemeliharaan, dan pengendalian lingkungan. Perusahaan dalam menjalankan aktivitasnya memerlukan sumber daya alam dan sumber daya manusia, tetapi perlu diketahui bahwa sumber daya alam yang diperlukan juga bisa habis bila tidak dikelola dan diperbaharui. Oleh sebab itu diperlukan pengelolaan sumber daya alam yang baik dan bijaksana. Perusahaan dituntut untuk melaksanakan Corporate Social Responsibility (CSR) dan pengungkapannya dalam pelestarian lingkungan hidup untuk menjaga keseimbangan antara kepentingan perusahaan terhadap keberlangsungan lingkungan dan juga demi terciptanya pemenuhan tuntutan akan informasi lingkungan.

Menurut Risa, dkk. (2011) tanggung jawab sosial atau Corporate Social Responsibility (CSR) adalah kontribusi perusahaan kepada masyarakat dan lingkungan sekitar atas profit yang didapat perusahaan yang berasal dari aktivitas bisnis. Aktivitas bisnis perusahaan tersebut sering kali menimbulkan kerusakan lingkungan dan dampak sosial bagi masyarakat sekitar yang diakibatkan oleh aktivitas perusahaan (Hidayat, 2016). Apabila perusahaan melakukan tanggung jawab sosial sesuai aturan yang ditetapkan, perusahaan akan dapat meminimalisir 
klaim dari masyarakat dan pemerintah serta meningkatkan citra dan nilai perusahaan yang pada akhirnya akan dapat meningkatkan keuntungan ekonomi.

Saat ini pelaksaan Corporate Social Responsibility (CSR) telah diatur dalam beberapa regulasi yang sifatnya mengikat agar perusahaan wajib melaksanakan tanggung jawab sosialnya. Hal ini diatur dalam Undang-Undang Nomor 40 Tahun 2007 tentang Perseroan Terbatas, Peraturan Pemerintah Nomor 47 Tahun 2012 tentang Tanggung Jawab Sosial dan Lingkungan Perseroan Terbatas, Undang-Undang No. 32 Tahun 2009 tentang Perlindungan dan Pengelolaan Lingkungan Hidup, Undang-Undang Nomor 25 Tahun 2007 tentang Penanaman Modal, Undang-Undang Nomor 22 Tahun 2001 tentang Minyak dan Gas Bumi, Undang-Undang Nomor 4 Tahun 2009 tentang Pertambangan Mineral dan Batubara, Peraturan Pemerintah Nomor 23 Tahun 2010 tentang Pelaksanaan Kegiatan Usaha Pertambangan Mineral dan Batubara, Undang-Undang Nomor 21 Tahun 2014 tentang Panas Bumi, Peraturan Pemerintah Nomor 74 Tahun 2001 Tentang Pengelolaan Bahan Berbahaya dan Beracun, dan Undang-Undang Nomor 13 Tahun 2011 Tentang Penanganan Fakir Miskin.

Beberapa penelitian tentang pengaruh Corporate Social Responsibility $(C S R)$ terhadap nilai perusahaan tidak selalu mendapatkan hasil yang konsisten, seperti penelitian yang dilakukan oleh Nurani (2015) dan Rosiana, dkk. (2013) menunjukan hasil bahwa Corporate Social Responsibility (CSR) berpengaruh positif dan signifikan terhadap nilai perusahaan, sedangkan penelitian yang dilakukan Puspaningrum (2014) menunjukan bahwa Corporate Social Responsibility (CSR) berpengaruh negatif dan tidak signifikan terhadap nilai 
perusahaan, dan hasil penelitian yang dilakukan oleh Ramona, dkk. (2017) juga menunjukan hasil yang berbeda yaitu Corporate Social Responsibility (CSR) tidak berpengaruh terhadap nilai perusahaan.

Penelitian yang dilakukan oleh beberapa peneliti menunjukan hasil yang tidak konsisten, yang kemungkinan diakibatkan adanya faktor lain yang turut mempengaruhi hubungan Corporate Social Responsibility (CSR) terhadap nilai perusahaan. Kinerja lingkungan diharapkan dapat menjadi informasi sosial yang bernilai tambah yang dapat mempengaruhi persepsi investor untuk menanamkan modalnya pada perusahaan (Bahri \& Cahyani, 2016). Kinerja lingkungan diduga dapat memperkuat pengaruh Corporate Social Responsibility (CSR) terhadap nilai perusahaan, sehingga dalam penelitian ini ditambahkan kinerja lingkungan sebagai variabel pemoderasi.

Kinerja lingkungan adalah hasil yang didapat perusahaan dari usaha pelestarian lingkungan dan pemenuhan tanggung jawab terhadap lingkungan (Arieftiara \& Venusita, 2017). Kinerja lingkungan dalam penelitian ini diukur dengan Program Penilaian Peringkat Kinerja Perusahaan (PROPER). PROPER merupakan salah satu upaya Kementerian Lingkungan Hidup untuk mendorong perusahaan dalam pengelolaan lingkungan hidup melalui pengungkapan informasi. Program ini diharapkan dapat mendorong perusahaan untuk menaati peraturan perundang-undangan dan menerapkan cleaner production (www.menlh.go.id).

Sistem peringkat kinerja PROPER mencakup 5 (lima) peringkat warna yaitu hitam, merah, biru, hijau dan emas. Perusahaan dengan perolehan peringkat 
PROPER yang baik, merupakan hal positif yang dapat direspon oleh investor atau calon investor. Hal tersebut karena perusahaan dianggap telah melakukan pengelolaan lingkungan dan secara konsisten menunjukkan keunggulan lingkungan dalam proses produksi barang atau jasa. Kondisi ini diduga dapat mendorong peningkatan nilai perusahaan melalui kenaikan harga saham. Kinerja lingkungan diduga akan memperkuat pengaruh Pengungkapan Corporate Social Responsibility (CSR) terhadap Nilai Perusahaan.

Dalam penelitian ini adalah Corporate Social Responsibility (CSR) diproksikan dengan Global Reporting Index (GRI) G4, sedangkan kinerja lingkungan diukur dengan Program Penilaian Peringkat Kinerja Perusahaan (PROPER). Penilaian PROPER dilakukan oleh Kementerian Lingkungan Hidup yang juga turut melibatkan masyarakat. Adapun perbedaan antara penelitian ini dengan penelitian Nurani (2015) adalah penelitian yang dilakukan Nurani (2015) meneliti perusahaan pertambangan, perkebunan dan kehutanan yang terdaftar di BEI tahun 2011-2013, sedangkan penelitian ini menggunakan sektor industri dasar dan kimia, aneka industri dan pertambangan tahun 2015-2017. Alasan pemilihan sektor industri dasar dan kimia, aneka industri dan pertambangan adalah dipilih dalam penelitian ini karena berhubungan langsung dengan sumber daya alam serta mempunyai dampak yang besar terhadap aspek sosial dan lingkungan.

Akuntansi memudahkan berbagi informasi dan meningkatkan transparansi dari proses operasi (Dillard, et al., 2005). Bentuk pertanggungjawaban akuntansi ini tentu saja harus diwujudkan dalam bentuk laporan keuangan dengan 
menyajikan dan mengungkapkan setiap materi akuntansi informasi yang dibutuhkan (Gunawan, 2012). Selain itu menurut Susanti (2017) tanggung jawab sosial perusahaan juga diwujudkan dengan pembangunan berkelanjutan, dan juga mempertimbangkan harapan pemangku kepentingan, sejalan dengan hukum yang ditetapkan dan norma-norma yang berlaku.

Perusahaan akan mengkomunikasikan aktivitas yang berhubungan dengan lingkungan melalui pengungkapan lingkungan untuk tetap mendapatkan legitimasi (Berthelot \& Robert, A., 2011). Pengungkapan lingkungan dianggap berguna untuk mengembalikan, meningkatkan, dan mempertahankan legitimasi (Hadjoh \& Sukartha, 2013). Jadi pada dasarnya teori legitimasi ini menjadi landasan bagi perusahaan untuk memperhatikan apa yang menjadi harapan masyarakat dan mampu menyelarasakan nilai-nilainya dengan norma-norma sosial yang dijunjung masyarakat di tempat perusahaan tersebut melakukan kegiatan operasinya.

Stakeholder adalah seseorang atau kelompok yang dapat mempengaruhi dan atau dipengaruhi oleh organisasi sebagai dampak dari aktivitas-aktivitasnya (Freeman, R., 1984). Stakeholder Theory menyatakan bahwa perusahaan tidak hanya beroperasi untuk kepentingannya sendiri namun harus berguna bagi stakeholdernya (Ghozali \& Chariri, 2007). Purnomosidhi (2006) menyatakan bahwa pemangku kepentingan berhak mengetahui informasi tentang aktivitas perusahaan yang dapat mempengaruhi pengambilan keputusan mereka. Dengan demikian, keberadaan perusahaan dipengaruhi oleh dukungan stakeholder dan 
dukungan tersebut harus dicari sehingga aktivitas perusahaan adalah untuk mencari dukungan tersebut (Gray, et al., 1997).

Teori stakeholder berhubungan dengan konsep tanggung jawab sosial perusahaan, tanggung jawab perusahaan tidak hanya terbatas untuk memaksimakan profit dan kepentingan pemegang saham, tetapi juga harus memperhatikan masyarakat, konsumen, pemerintah dan pemasok sebagai bagian dari operasi perusahaan itu sendiri. Menurut Wardhana (2017) stakeholder memiliki hak untuk mengetahui tindakan yang dilakukan oleh manajemen, seperti hak untuk mengetahui kinerja finansial, lingkungan, serta tanggung jawab sosial, informasi tersebut dapat digunakan untuk menilai kinerja perusahaan, semakin banyak harapan stakeholder yang terpenuhi maka akan meningkatkan nilai perusahaan.

Teori sinyal menjelaskan bahwa keputusan investasi pihak luar perusahaan akan sangat bergantung oleh informasi yang dikeluarkan oleh perusahaan. Menurut Hartono (2007:392) informasi yang diumumkan oleh perusahaan akan memberikan sinyal bagi investor dalam mengambil keputusan untuk investasi, jika pengumuman tersebut mengandung nilai positif, maka pasar akan bereaksi pada waktu pengumuman tersebut diterima.

Lujun dalam Octavia (2012) menyatakan bahwa perusahaan dengan kinerja lingkungan yang baik memiliki insentif untuk mengungkapkan informasi lingkungan dalam laporan tahunan. Apabila perusahaan melakukan pengungkapan lingkungan, perusahaan akan dapat meningkatkan transparansi. Transparansi 
pengungkapan lingkungan akan membuat laporan yang dihasilkan oleh perusahaan menjadi lebih dapat diandalkan.

Octavia (2012) menyatakan bahwa investor akan lebih tertarik terhadap perusahaan yang melakukan kinerja dan pengungkapan lingkungan secara berkelanjutan. Sehingga, apabila hal tersebut terus dilaksanakan oleh perusahaan maka akan meningkatkan nilai perusahaan. Menurut Verrecchia (1983), perusahaan cenderung mengungkapkan hal-hal yang bersifat good news dan cenderung menghindari untuk mengungkapkan hal yang bersifat bad news.

Menurut Fisher (1998) teori kontinjensi didasarkan pada gagasan bahwa desain dan sistem pengendalian tergantung pada konteks organisasi di mana pengendalian tersebut dilaksanakan. Teori kontingensi timbul sebagai respon dari pendekatan universal yang menyatakan bahwa desain pengendalian yang optimal itu dapat diterima pada semua pengaturan dan perusahaan (Instanti, 2009). Sistem akuntansi manajemen adalah suatu pendekatan kontinjensi dari faktor kondisional yang digunakan dalam penelitian sebagai variabel yang memoderasi suatu hubungan (Suranta, 2013).

Menurut Indrayanti, dkk. (2017) berdasarkan teori kontinjensi maka terdapat faktor situasional lain yang mungkin akan saling berinteraksi dalam suatu kondisi tertentu. Govindarajan (1988) menyatakan bahwa pendekatan kontinjensi dapat dipergunakan sebagai solusi atas ketidakkonsistenan hasil-hasil riset sebelumnya. Ketidakkonsistenan hasil penelitian diduga dipengaruhi oleh berbagai faktor atau variabel yang bersifat kondisional. 
Menurut Keown (2004) nilai perusahaan merupakan persepsi pemilik modal terhadap tingkat keberhasilan perusahaan yang dihubungkannya dengan harga saham. Nilai perusahaan yang tinggi bukan hanya karena kinerja perusahaan saat ini, tapi juga prospek perusahaan di masa depan

Secara umum perusahaan akan mengambil keputusan yang akan memaksimalkan nilai perusahaan (Suka, 2016). Memaksimalkan nilai perusahaan artinya mewujudkan kemakmuran pemegang saham (Brigham, E., F., dan Gapenski, 1996). Semakin tinggi harga saham semakin tinggi nilai perusahaan. Kemakmuran stakeholders dan perusahaan direpresentasikan oleh harga saham yang di pasar modal yang merupakan cermin dari keputusan investasi (Tjahjono, 2013).

Banyak perusahaan dalam industri menyadari bahwa masalah lingkungan dan sosial bagian penting dari perusahaan (Pflieger, 2004). Corporate Social Responsibility (CSR) merupakan bentuk aktualisasi tanggung jawab sosial perusahaan pada masyarakat. Menurut Darwin dalam Anggraini (2006) Corporate Social Responsibility (CSR) adalah mekanisme bagi suatu perusahaan untuk memberi perhatian pada lingkungan dan sosial yang melebihi tanggung jawab di bidang hukum. Wujud nyata dari pelaksanaan Corporate Social Responsibility (CSR) dalam upaya mensejahteraan masyarakat tertuang dalam kepedulian perusahaan yang menyisihkan sebagian keuntungannnya untuk kepentingan pembangunan manusia dan kelestarian lingkungan secara berkelanjutan.

Elkington (1998) merumuskan Corporate Social Responsibility (CSR) ke dalam tiga fokus, yaitu : 3P ( profit, planet, people). Menurut Limijaya (2014) 
tanggung jawab perusahaan harus berpijak pada Triple Bottom Lines (TBL), yaitu kepentingan dari sisi keberlangsungan laba (profit), masyarakat (people), dan lingkungan hidup (planet). Perusahaan yang baik tidak sekedar mencari keuntungan (profit) belaka tetapi perusahaan juga harus memiliki kepedulian terhadap kelestarian lingkungan (planet) dan kesejahteraan masyarakat (people) (Lingga \& Suaryana, 2017).

Penelitian yang dilakukan oleh Al Sharairi (2005) yang menunjukan bahwa biaya lingkungan yang diungkapkan perusahaan mampu meningkatkan citra perusahaan dan berpengaruh positif terhadap keunggulan kompetitif.

Menurut Ismail \& Simbolon (2013) pengungkapan akuntansi lingkungan menyangkut kegiatan-kegiatan pemeliharaan lingkungan oleh perusahaan yaitu mencakup kepentingan perusahaan-perusahaan publik yang bersifat lokal. Pentingnya pengungkapan terutama bagi para stakeholder untuk memahami, menilai dan menganalisis sehingga dapat memberikan dukungan bagi usaha mereka. Oleh sebab itu, akuntansi lingkungan telah menjadi bagian dari suatu sistem sosial perusahaan (Ismail \& Simbolon, 2013).

Akuntansi lingkungan tidak hanya menghitung cost dan benefit perusahaan, namun juga memperhitungkan biaya lingkungan yang merupakan biaya-biaya yang timbul di luar pasar. Belum adanya standar pengukuran dan penilaian dampak aktivitas perusahaan terhadap lingkungan adalah kendala yang dihadapi oleh akuntansi lingkungan, karena tidak semua biaya dan manfaat lingkungan mudah diidentifikasi dan diukur (Halim \& Irawan, 1998). 
Pengungkapan lingkungan merupakan istilah yang digunakan oleh suatu instansi atau organisasi untuk mengungkapkan informasi (release of information) yang berhubungan dengan lingkungan (www.menlh.go.id). Menurut Berthelot, et $a l$,. (2003) pengungkapan lingkungan adalah informasi yang berhubungan dengan aktivitas pengelolaan lingkungan di masa lalu, saat ini dan di masa depan dan informasi tentang implikasi keuangan di masa lalu, saat ini, dan masa depan yang dihasilkan dari perusahaan keputusan atau tindakan manajemen lingkungan.

Menurut Gray et al., (1997) dalam Meutya (2008) pengungkapan tanggung jawab sosial dan lingkungan oleh perusahaan bertujuan menunjukan aktivitas yang dilakukan oleh perusahaan dan pengaruh yang ditimbulkan kepada masyarakat. Standar pengungkapan lingkungan yang diakui dan diterapkan secara luas akan dapat membuat perusahaan mengetahui tanggung jawab mereka sekaligus membuat perusahaan untuk menyampaikan informasi yang bermanfaat yang dibutuhkan, di lain pihak juga dapat membantu manajemen dalam mempertimbangkan masalah lingkungan akibat aktivitas perusahaan (Nursasi, Enggar, 2017).

Menurut Ghozali \& Chariri (2007) perusahaan akan menyampaikan informasi yang diperlukan dalam rangka berjalannya fungsi pasar modal. Pendapat tersebut didukung dengan pernyataan Lingga \& Suaryana (2017) apabila suatu informasi tidak diungkapkan maka informasi tersebut tidak relevan bagi investor. Menurut Cormier dalam Dewati \& Syafruddin (2014) pengungkapan lingkungan yang informatif akan membawa nilai signifikan pada informasi perusahaan yang terkait dengan lingkungan. 
Menurut Purwanto (2000) kinerja lingkungan merupakan hasil dapat diukur dari sistem manajemen lingkungan, yang berhubungan pengkajian kinerja lingkungan didasarkan pada kebijakan lingkungan, sasaran lingkungan dan target lingkungan. Kinerja lingkungan adalah upaya yang dilakukan oleh perusahaan untuk mengurangi jejak atau dampak lingkungan yang mungkin diakibatkan oleh aktivitas operasinya (Albertini, 2013). Sedangkan menurut Porter \& Linde (1995) menyatakan bahwa peningkatan kinerja lingkungan adalah sumber informasi penting agar perusahaan dapat mencapai tingkatan produksi yang efisien, perbaikan produktivitas sesuai dengan standar keamanan, penekanan biaya yang disebabkan karena kerusakan lingkungan dan kesempatan memperoleh pasar baru. Perusahaan memberikan perhatian pada lingkungan sebagai bentuk tanggung jawab dan kepedulian perusahaan terhadap lingkungan (Fitriyani. \& Mutmainah, 2012).

Tujuan utama perusahaan adalah meningkatkan nilai perusahaaan. Berdasarkan Teori Legitimasi, perusahaan juga harus memperhatikan apa yang menjadi harapan masyarakat dan mampu menyelaraskan nilai-nilainya dengan norma-norma yang dijunjung masyarakat. Nilai perusahaan akan berkembang jika perusahaan memperhatikan aspek ekonomi, sosial dan lingkungan hidup. Aspek tersebut terdapat di dalam penerapan Corporate Social Responsibility (CSR) yang dilakukan perusahaan sebagai bentuk pertanggungjawaban dan kepedulian (2013), Retno dan Priantinah (2012), Nurani (2015) menunjukkan bahwa terhadap lingkungan di sekitar perusahaan (Kusumadilaga, 2010). 
Hasil penelitian yang dilakukan oleh Rosiana et al., (2013) Corporate Social Responsibility (CSR) berpengaruh positif terhadap nilai perusahaan. Apabila perusahan melakukan Corporate Social Responsibility (CSR), maka perusahaan akan dapat meningkatkan image perusahaan dimata stakeholders, melalui respon positif dimata masyarakat. Adanya perhatian perusahaan perusahaan terhadap lingkungan dan sosial, akan meningkatkan loyalitas konsumen terhadap perusahaan, yang secara tidak langsung dapat meningkatkan nilai perusahan. Dengan demikian, semakin baik penerapan Corporate Social Responsibility (CSR) oleh perusahaan maka akan meningkatan nilai perusahaan. Berdasarkan uraian diatas, maka hipotesis penelitian ini adalah dirumuskan sebagai berikut:

$\mathrm{H}_{1}$ : Corporate Social Responsibilty (CSR) berpengaruh positif pada nilai perusahaan.

Teori kontijensi menjelaskan bahwa tujuan perusahaan tidak hanya memaksimalkan laba, tetapi perusahaan juga harus memperhatikan kepentingan lain, seperti kepentingan masyarakat dan lingkungannya. Corporate Social Responsibility dilakukan perusahaan sebagai bentuk tanggung jawab dan perhatian perusahaan pada masyarakat dan lingkungan, dengan cara menyisihkan sebagian keuntungannya untuk kepentingan masyarakat dan lingkungan sekitar. Menurut Ghaesani. N. (2016) apabila perusahaan melakukan Corporate Social Responsibility perusahaan akan memiliki citra yang baik sehingga akan lebih diminati oleh para investor, hal ini sejalan dengan penelitian yang dilakukan Chen \& Lee (2017) dan Yuniasih \& Wirakusuma (2007) bahwa CSR berpengaruh positif terhadap nilai perusahaan. 
Menurut Handayati \& Rochayatun (2015) kinerja lingkungan adalah usaha perusahaan untuk melestarikan dan mewujudkan keselarasan antara kepentingan perusahaan dan keberlangsungan lingkungan. Kinerja lingkungan sebagai variabel moderasi diduga dapat memperkuat hubungan Corporate Social Responsibility (CSR) dan nilai perusahaan. Kinerja Lingkungan diharapkan menjadi informasi sosial yang mempengaruhi persepsi investor untuk menanamkan modal sehingga dapat meningkatkan nilai perusahaan.

$\mathrm{H}_{2}$ : Kinerja Lingkungan memperkuat hubungan antara Corporate Sosial Responsibility (CSR) dan Nilai Perusahaan.

\section{METODE PENELITIAN}

Penelitian ini dilakukan pada perusahaan yang terdaftar di Bursa Efek Indonesia Sektor Industri Dasar dan Kimia, Aneka Industri, dan Pertambangan yang menjadi peserta PROPER Tahun 2015-2017 dengan mengakses situs http://idx.co.id dan situs www.menlh.go.id untuk mendapatkan informasi dan data yang diperlukan.

Obyek yang diteliti pada penelitian ini adalah kinerja lingkungan dan Corporate Social Responsibility (CSR) terhadap nilai perusahaan pada Bursa Efek Indonesia Sektor Industri Dasar dan Kimia, Aneka Industri dan Pertambangan Tahun 2015-2017.

Cara menghitung pengungkapan $C S R$ secara keseluruhan adalah dengan menjumlahkan hasil dari perhitungan masing-masing indikator pengungkapan $C S R$. Untuk mengukur tingkat pengungkapan $C S R$ penelitian ini menggunakan score pengungkapan $C S R$. Pendekatan untuk menghitung $C S R$ pada dasarnya 
menggunakan pendekatan dikotomi yaitu setiap item CSR dalam instrumen penelitian diberi nilai 1 jika diungkapkan, dan nilai 0 jika tidak diungkapkan (Haniffa \& Cooke, 2005). Selanjutnya, skor dari setiap item dijumlahkan untuk memperoleh keseluruhan skor untuk setiap perusahaan. Menurut Sudarma \& Darmayanti (2017) skor diukur dengan menggunakan persamaan sebagai berikut:

$\mathrm{CSRDIj}=\frac{\sum \mathrm{Xij}}{\mathrm{Nj}}$

Keterangan :

CSRIDj= Jumlah score pengungkapan CSR

$\sum \mathrm{Xij}=$ Jumlah item yang diungkapkan perusahaan

$\mathrm{Nj} \quad=$ jumlah item pengungkapan CSR

Menurut Adelina, dkk. (2014) nilai perusahaan diukur menggunakan rumus Tobin's Q sebagai berikut :

Tobins' $\mathrm{Q}=\frac{\mathrm{MVE}_{\mathrm{t}}+\mathrm{DEBT}_{\mathrm{t}}}{\mathrm{TA}_{\mathrm{t}}}$

Keterangan:

Tobins'Q = Nilai Perusahaan.

MVE $_{\mathrm{t}} \quad=$ Closing price saham akhir tahun $\times$ jumlah saham beredar akhir tahun pada periode $\mathrm{t}$.

DEBT $_{\mathrm{t}} \quad=$ Total liabilitas perusahaan pada periode $\mathrm{t}$.

$\mathrm{TA}_{\mathrm{t}} \quad=$ Total aktiva perusahaan pada periode $\mathrm{t}$.

Populasi dalam penelitian ini adalah Sektor Industri Dasar dan Kimia, Aneka Industri dan Pertambangan yang terdaftar di Bursa Efek Indonesia (BEI) tahun 2015-2017. Sampel yang digunakan dalam penelitian ini adalah perusahaan yang tercatat di Bursa Efek Indonesia (BEI) tahun 2015-2017.

Teknik analisis data yang digunakan dalam penelitian ini adalah Moderated Regression Analysis (MRA) dengan Uji Selisih Mutlak. Adapun model regresi ditunjukan dalam persamaan sebagai berikut : 
$Y=\alpha+\beta_{1} X_{1}+\beta_{2} X_{2}+\beta_{3} \mid X_{1}-X_{2}$

Keterangan :

$\mathrm{Y}=$ Nilai Perusahaan

$\alpha \quad=$ Konstanta

$\beta_{1} \quad=$ Koefisien regresi variabel Corporate Social Responsibility

$\beta_{2} \quad=$ Koefisien regresi variabel Kinerja Lingkungan

$\beta_{3} \quad=$ Koefisien regresi Interaksi antara CSR dengan Kinerja Lingkungan

$X_{1}=$ Corporate Social Responsibility

$X_{2} \quad=$ Kinerja Lingkungan

\section{HASIL DAN PEMBAHASAN}

Statistik deskriptif disajikan untuk memberikan informasi mengenai karakteristik variabel-variabel penelitian, yaitu jumlah sampel, nilai maksimum, nilai minimum, nilai rata-rata dan standar deviasi. Hasil statistik deskriptif penelitian ini dapat dilihat pada Tabel 1 sebagai berikut.

Tabel 1. Hasil Uji Statistik Deskriptif

\begin{tabular}{llllll}
\hline & N & Minimum & Maximum & Mean & Std. Deviation \\
\hline CSR & 129 & 0.001 & 0.901 & 0.24703 & 0.126579 \\
Kinerja Lingkungan & 129 & 2.000 & 5.000 & 3.06202 & 0.511614 \\
CSR_Kinerja Lingkunga $]$ & 129 & 0.003 & 3.604 & 0.78776 & 0,541742 \\
Nilai Perusahaan & 129 & 0.001 & 8.210 & 1.36796 & 1.280774 \\
\hline
\end{tabular}

Sumber: Data diolah, 2018

Nilai rata-rata Corporate Social Responsibility (CSR) dari 129 sampel adalah sebesar 0,24703 , nilai ini cenderung rendah dibandingkan dengan nilai maksimumnya sebesar 0,901 yang terdapat pada PT Aneka Tambang tahun 2015, sedangkan nilai minimum sebesar 0,001 terdapat pada PT Timah pada tahun 2016.

Nilai rata-rata Kinerja lingkungan dari 129 sampel adalah sebesar 3,06202, dengan standar deviasi sebesar 0,511614. Nilai minimum sebesar 2, sedangkan nilai maksimum sebesar 5 . 
Interaksi Corporate Social Responsibility (CSR) dan kinerja lingkungan dari 129 sampel adalah sebesar 0,78776, nilai ini cenderung rendah dibandingkan dengan nilai maksimumnya sebesar 3,604, sedangkan nilai minimumnya sebesar 0,003 .

Nilai rata-rata Nilai perusahaan dari 129 sampel adalah sebesar 1,38567, nilai ini cenderung rendah dibandingkan nilai maksimumnya sebesar 8,210 yang terdapat pada PT. Pelat Timah Nusantara tahun 2017, sedangkan nilai minimum sebesar 0,001 terdapat pada PT. Budi Starch \& Sweetener tahun 2016.

Pengujian normalitas data dalam penelitian ini dilakukan dengan uji Kolmogorov-Smirnov atau K-S dengan bantuan Software Statistic Package for the Social Science (SPSS) for Windows. Jika siginifikansi nilai residual > 0,05 berarti residual berdistribusi secara normal. Hasil dari uji normalitas disajikan dalam Tabel 2 sebagai berikut.

Tabel 2.

Hasil Uji Normalitas

\begin{tabular}{ccc}
\hline $\mathbf{N}$ & $\mathbf{Z}$ & Asymp.Sig \\
\hline 129 & 1.134 & 0.153 \\
\hline
\end{tabular}

Sumber: Data diolah, 2018

Berdasarkan Tabel 2, taraf signifikansi untuk persamaan regresi moderasi adalah sebesarr 0,153 dengan taraf signifikansi $>0,05$ menunjukkan bahwa data penelitian ini berdistribusi normal.

Uji heteroskedastisitas dalam penelitian ini menggunakan uji Glejser, uji Glejser dilakukan dengan meregresikan variabel bebas terhadap absolute residual. Jika tingkat signifikansi masing-masing variabel $>0,05$ maka dapat disimpulkan bahwa model regresi bebas mengandung adanya heteroskedastisitas. 
Tabel 3.

Hasil Uji Heteroskedastisitas

\begin{tabular}{cc}
\hline Variabel & Sig. \\
\hline Zx1 & 0.139 \\
Zx2 & 0.571 \\
Zx1_Zx2 & 0.245 \\
\hline
\end{tabular}

Sumber: Data diolah, 2018

Berdasarkan Tabel 3 maka dapat disimpulkan bahwa data terbebas dari heteroskedastisitas. Hal itu ditunjukkan dengan keseluruhan nilai variabel berada pada tingkat signifikansi $>0,05$.

Untuk mendeteksi ada tidaknya autokorelasi dilakukan dengan menggunakan Uji Durbin-Watson (DW-Test) dengan ketentuan du $<\mathrm{dw}<(4-$ du). Hasil uji autokorelasi disajikan dalam Tabel 4.sebagai berikut.

Tabel 4.

Hasil Uji Autokorealasi

\begin{tabular}{cc}
\hline DW (Durbin Watson) & Keterangan \\
\hline 2.056 & $\mathrm{du}<\mathrm{dw}<(4-\mathrm{du})$ \\
\hline Sumber: Data diolah, 2018 &
\end{tabular}

Berdasarkan Tabel 4 diatas, hasil uji autokorelasi menunjukkan nilai DW sebesar 2,056. Hasil tersebut dibandingkan dengan nilai tabel DW menggunakan nilai signifikansi 5\%, jumlah sampel (n) 129 dan jumlah variabel independen 1 $(\mathrm{k}=1)$ diperoleh nilai $\mathrm{dL}=1,6969$ dan $\mathrm{dU}=1,7281$. Oleh karena $\mathrm{du}<\mathrm{dw}<4-\mathrm{du}$ yaitu $1,7281<2,056<2,2719$ maka dalam penelitian ini tidak terjadi gejala autokorelasi. Semua uji asumsi klasik telah memenuhi syarat maka uji nilai selisih mutlak dilanjutkan.

Pengolahan data menggunakan Moderated Regression Analysis (MRA) dengan uji Nilai Selisih Mutlak menggunakan program SPSS. Berikut adalah hasil dari uji nilai selisih mutlak yang disajikan dalam Tabel 5. 
Tabel 5.

Hasil Moderated Regression Analysis (MRA)

\begin{tabular}{|c|c|c|c|c|c|}
\hline \multirow[b]{2}{*}{ Model } & \multicolumn{2}{|c|}{$\begin{array}{l}\text { Unstandardized } \\
\text { Coefficients }\end{array}$} & \multicolumn{2}{|l|}{$\begin{array}{c}\text { Standardized } \\
\text { Coefficients }\end{array}$} & \multirow[b]{2}{*}{ Sig } \\
\hline & B & Std. Error & Beta & $\mathbf{T}$ & \\
\hline (Constant) & 1.231 & 0.160 & & 7.713 & 0.000 \\
\hline CSR & 0.273 & 0.130 & 0.213 & 2.103 & 0.037 \\
\hline Kinerja Lingkungan & -0.013 & 0.127 & -0.010 & $-0,104$ & 0.918 \\
\hline CSR_Kinerja Lingkungan & 0.192 & 0.162 & 0.107 & 1.183 & 0,239 \\
\hline $\begin{array}{ll}\text { Adjusted } R^{2} & =0.045 \\
\text { F Hitung } & =3.004\end{array}$ & & & & & \\
\hline$=0.033$ & & & & & \\
\hline
\end{tabular}

Berdasarkan Tabel 5 maka dapat disimpulkan hasil regresi sebagai berikut.

$\mathrm{Y}=1,231+0,273 X_{1}-0,013 X_{2}+0,192\left|X_{1}-X_{2}\right|$

Nilai konstanta sebesar 1,231 memiliki arti apabila semua variabel independen konstan, maka nilai perusahaan akan naik sebesar 1,231 persen. Nilai koefisien regresi Corporate Social Responsibility (CSR) sebesar 0,273 memiliki arti jika Corporate Social Responsibility (CSR) meningkat sebesar 1 satuan, maka nilai perusahaan akan meningkat sebesar 27,3 persen dengan asumsi semua variabel independen lainnya konstan. Nilai koefisien regresi kinerja lingkungan sebesar 0,013 memiliki arti jika kinerja lingkungan meningkat sebesar 1 satuan, maka nilai perusahaan akan menurun sebesar 1,3 persen dengan asumsi semua variabel independen lainnya konstan. Nilai koefisien regresi interaksi Corporate Social Responsibility (CSR) dan kinerja lingkungan sebesar 0,192 memiliki arti jika regresi interaksi Corporate Social Responsibility (CSR) dan kinerja lingkungan naik sebesar 1 satuan, maka nilai perusahaan akan naik sebesar 19,2 persen dengan asumsi semua variabel independen lainnya konstan.

Koefisien determinasi $\left(\mathrm{R}^{2}\right)$ diukur untuk mengetahui presentase pengaruh variabel independen terhadap perubahan variabel dependen. Koefisien determinasi 
pada model regresi dilihat dari nilai Adjusted $\mathrm{R}^{2}$. Pada Tabel 5 nilai Adjusted $\mathrm{R}^{2}$ sebesar 0,045 atau 4,5 persen. Hal ini berarti bahwa variasi variabel nilai perusahaan yang diproksikan denga Tobins' $Q$ dapat dijelaskan sebesar 4,5 persen oleh variasi variabel CSR dan kinerja lingkungan sedangkan sisanya sebesar 95,5 persen dipengaruhi oleh variabel lain.

Uji kelayakan model (Uji F) digunakan untuk mengetahui apakah model regresi Moderated Regression Analysis (MRA) dalam penelitian ini layak digunakan atau tidak. Pada Tabel 5 nilai $\mathrm{F}$ hitung sebesar 3,004 dengan signifikansi 0,033. Nilai signifikansi tesebut lebih kecil dari level signifikansi 0,05. Jadi dapat disimpulkan bahwa model Moderated Regression Analysis (MRA) layak digunakan.

Hasil pengujian hipotesis menunjukan bahwa koefisien regresi Corporate Social Responsibility (CSR) memiliki nilai sebesar 0,273 dengan tingkat signifikansi sebesar 0,037. Tingkat signifikansi lebih kecil dari level signifikansi $\alpha$ $=0,05$, yang artinya sesuai dengan hipotesis yang diharapkan sehingga $\mathrm{H}_{1}$ diterima. Hal ini menunjukan bahwa Corporate Social Responsibility (CSR) berpengaruh positif dan signifikan pada nilai perusahaan.

Hasil pengujian hipotesis menunjukan bahwa regresi moderasi memiliki nilai sebesar $-0,013$ dengan tingkat signifikansi sebesar 0,918. Tingkat signifikansi lebih besar dari level signifikansi $\alpha=0,05$, yang artinya $\mathrm{H}_{2}$ ditolak. Hal ini menunjukan bahwa kinerja lingkungan tidak mampu memperkuat pengaruh Corporate Social Responsibility (CSR) pada nilai perusahaan. 
Corporate Social Responsibility (CSR) adalah bentuk perhatian perusahaan pada masyarakat dan lingkungan sekitar dengan menyisihkan sebagian keuntungannya untuk kepentingan pembangunan manusia dan kelestarian lingkungan. Apabila perusahaan melakukan Corporate Social Responsibility (CSR) perusahaan akan dapat meningkatkan citra perusahaan dimata pemangku kepentingan, dengan citra yang baik perusahaan dapat meningkatkan loyalitas konsumen terhadap perusahaan, sehingga secara tidak langsung dapat meningkatkan nilai perusahaan yang tercermin dari harga sahamnya.

Hasil penelitian yang dilakukan Rosiana, dkk. (2013), Retno \& Prihatinah (2012), dan Agustina (2013) menunjukan bahwa Corporate Social Responsibility (CSR) berpengaruh positif terhadap nilai perusahaan. Teori legitimasi mampu memprediksi hubungan positif antara Corporate Social Responsibility (CSR) dan nilai perusahaan. Berdasarkan Teori Legitimasi, perusahaan harus memperhatikan apa yang menjadi harapan masyarakat dan mampu menyelaraskan nilai-nilainya dengan norma-norma yang dijunjung masyarakat. Nilai perusahaan akan berkembang jika perusahaan memperhatikan aspek ekonomi, sosial dan lingkungan hidup. Aspek tersebut terdapat di dalam penerapan Corporate Social Responsibility (CSR) yang dilakukan perusahaan sebagai bentuk pertanggungjawaban dan kepedulian terhadap lingkungan di sekitar perusahaan (Kusumadilaga, 2010). Dengan melakukan Corporate Social Responsibility (CSR) perusahaan akan dapat meningkatkan citra positif dimata masyarakat, dimana citra positif tersebut juga sangat penting bagi eksistensi dan kelangsungan hidup 
perusahaan (going concern). Oleh karena itu perusahaan berusaha mendapatkan legitimasi dari masyarakat.

Salah satu bentuk tanggung jawab dan kepedulian perusahaan tertuang pada kinerja lingkungan dengan mengikuti Program Penilaian Peningkat Kinerja Perusahaan dalam Pengelolaan Lingkungan (PROPER). PROPER diharapkan dapat mendorong perusahaan dalam mengelola lingkungan hidup melalui instrumen informasi. Kinerja Lingkungan diharapkan menjadi informasi sosial yang mempengaruhi persepsi investor untuk menanamkan modal sehingga dapat meningkatkan nilai perusahaan.

Penelitian yang dilakukan Nurani (2015) menunjukan bahwa kinerja lingkungan tidak memiliki pengaruh yang signifikan terhadap hubungan Corporate Social Responsibility (CSR) dan nilai perusahaan. Dengan kata lain perusahaan yang mengikuti PROPER tidak dapat mempengaruhi perusahaan dalam mengungkapkan Corporate Social Responsibility (CSR) dalam meningkatkan nilai perusahaan. Hal ini dikarenakan tidak semua investor melihat kinerja lingkungan sebagai kriteria dalam berinvestasi karena kinerja lingkungan yang baik belum tentu menunjukan suatu perusahaan dapat memberikan dampak atau keuntungan bagi para investor. Peringkat PROPER belum mampu menaikan citra perusahaan dimata investor

Menurut Indrayanti, dkk. (2017) berdasarkan teori kontinjensi maka terdapat faktor situasional lain yang mungkin akan saling berinteraksi dalam suatu kondisi tertentu. Teori kontingensi bertolak belakang dalam penelitian ini karena 
Veronica Padma Lingga dan M. G. Wirakusuma. Pengaruh Corporate Social...

kinerja lingkungan tidak terbukti dapat mempengaruhi Corporate Social Responsibility (CSR) yang berdampak pada naiknya nilai perusahaan.

Berdasarkan penelitian yang telah dilakukan dapat diketahui bahwa secara teoritis, penelitian ini mendukung teori legitimasi, teori stakeholder, dan teori sinyal yang telah ada sebelumnya. Penelitian ini dapat menjadi suatu hal baru untuk penelitian yang berhubungan dengan variabel Corporate Social Responsibility (CSR), nilai perusahaan, dan kinerja lingkungan. Pengolahan data dilakukan dengan menggunakan Moderated Regression Analysis (MRA) untuk memperkirakan hubungan antara variabel - variabel yang telah ditetapkan sebelumnya berdasarkan teori. Hasil penelitian ini dapat digunakan untuk memperkaya referensi yang berkaitan dengan Corporate Social Responsibility $(C S R)$, nilai perusahaan, dan kinerja lingkungan

Hasil penelitian ini dapat menjadi bahan pertimbangan bagi investor maupun calon investor dalam mengambil keputusan untuk berinvestasi dengan melihat Corporate Social Responsibility (CSR), nilai perusahaan, dan kinerja lingkungan sehingga tidak hanya terpaku pada ukuran-ukuran moneter. Peringkat kinerja lingkungan yang baik serta melaksanakan CSR dengan baik, membuat perusahaan telah dianggap mampu bertanggung jawab atas lingkungan sekitarnya. Apabila perusahaan telah mampu bertanggung jawab atas lingkungan, perusahaan dinilai telah memiliki etika bisnis yang baik.

\section{SIMPULAN}


Variabel Corporate Social Responsibility (CSR) berpengaruh positif pada nilai perusahaan yang terdaftar di Bursa Efek Indonesia sektor industri dasar dan kimia, aneka industri dan pertambangan tahun 2015-2017

Kinerja lingkungan tidak mampu memoderasi pengaruh Corporate Social Responsibility (CSR) pada nilai perusahaan yang terdaftar di Bursa Efek Indonesia sektor industri dasar dan kimia, aneka industri dan pertambangan tahun 2015-2017

Bagi pihak manajemen, diharapkan berkomitmen untuk mengungkapkan aktivitas pengelolaan lingkungan secara lebih transparan, terutama yang berdampak positif bagi lingkungan sekitarnya. Diharapkan dengan melakukan pengungkapan lingkungan dapat membantu perusahaan mendapat dukungan dari lingkungan sekitar maupun orang yang berkepentingan pada perusahaan

Bagi pihak stakeholder terutama pihak investor dan kreditor yang berhubungan langsung dengan perusahaan agar memperhatikan pengungkapan lingkungan (environmental disclosure) yang dilakukan oleh manajemen perusahaan, untuk cermat dalam mengambil keputusan investasi.

Bagi peneliti selanjutnya, diharapkan menggunakan indikator lain untuk mengukur kinerja lingkungan seperti ISO 9001 dan ISO14001. ISO 9001 dan ISO 14001 adalah salah satu standar internasional dalam mengukur mutu organisasi, selain itu ISO dianggap dapat meningkatkan kepercayaan kredibilitas perusahaan serta kepercayaan pelanggan sehingga dapat meningkatkan nilai perusahaan.

\section{REFERENSI}

Adelina, S., Agusti, R., \& M, B. Y. (2014). Pengaruh Rasio Likuiditas, Leverage dan Profitabilitas Terhadap Nilai Perusahaan Pada Industri Barang Konsumsi 
yang Terdaftar di Bursa Efek Indonesia Tahun 2010-2012. Jurnal Online Fakultas Ekonomi Universitas Riau, 1(2), 1-15.

Albertini, E. (2013). Does Environmental Management Improve Financial Performance? A Meta-Analytical Review. Journal of Organization \& Environment, 26(4), 431-457.

Anggraini, F. R., R. (2006). Pengungkapan Informasi Sosial dan Faktor-faktor yang Mempengaruhi Pengungkapan Informasi Sosial dalam Laporan Keuangan Tahunan. Simposium Nasional Akuntansi IX.

Arieftiara, D., \& Venusita, L. (2017). Pengaruh Kinerja Lingkungan dan Intensitas Persaingan terhadap Nilai Perusahaan dalam rangka Mendukung Sustainability Development.

Bahri, S., \& Cahyani, F. A. (2016). Pengaruh kinerja lingkungan terhadap corporate financial performance dengan corporate social responsibility disclosure sebagai variabel intervening. Jurnal Ekonomi Universitas Kediri, 1(2), 117-142.

Berthelot, S., Cormier, D., \& Magnan, M. (2003). Environmental disclosure research: Review and synthesis. Journal Of Accounting Literature, 22.

Berthelot, S., \& Robert, A., M. (2011). Climate change disclosure: An examination of Canadian oil and gas firms. Issues in Social and Environmental Accounting, 5(1).

Brigham, E., F., dan Gapenski, L. C. (1996). Intermadiate finance management. 5th ed. Harbor Drive: The Dryden Press.

Chen, R. C. Y., \& Lee, C. H. (2017). The influence of CSR on firm value: an application of panel smooth transition regression on Taiwan. Applied Economics, 49(34).

Dewati, S. A., \& Syafruddin, M. (2014). Kualitas Pengungkapan Lingkungan: Perspektif dari Kinerja Lingkungan, Corporate Governance, dan Relevansi Nilai. Skripsi. Sarjana Jurusan Akuntansi pada Fakultas Ekonomi dan Bisnis Universitas Diponegoro.

Dillard, J., Brown, D., \& Marshall, R. S. (2005). An environmentally enlightened accounting. Accounting Forum, 29(1).

Elkington, J. (1998). Cannibals With Forks: The Triple Bottom Line in 21st Century Business. Gabriola Island, BC: New Society Publishers.

Fisher, J. (1998). Contingency theory, management control systems and firm 
outcomes: past results and future directions. Behavioral Research in Accounting, 10.

Fitriyani., \& Mutmainah, S. (2012). Keterkaitan Kinerja Lingkungan, Pengungkapan Corporate Social Responsibility (CSR) dan Kinerja Finansial. Skripsi. Sarjana Jurusan Akuntansi pada Fakultas Ekonomi dan Bisnis Universitas Diponegoro.

Freeman, R., E. (1984). Strategic Management: A Stakeholder Approach. Boston: Pitman Publishing.

Ghaesani. N., S. (2016). Pengaruh Pengungkapan Corporate Social Responsibility, Profitabilitas, Ukuran Perusahaan Terhadap Nilai Perusahaan.

Ghozali, I., \& Chariri, A. (2007). Teori Akuntansi. Semarang : Badan Penerbit Universitas Diponegoro.

Govindarajan, V. (1988). A contingency approach to strategy implementation at the business-unit level: Integrating administrative mechanisms with strategy. Academy of Management Journal, 31(4).

Gray, Clifford, \& Larson. (1997). Manajemen Proyek. LPFE Universitas Indonesia

Gunawan, E. (2012). Tinjauan Teoritis Biaya Lingkungan terhadap Kualitas Produk dan Konsekuensinya terhadap Keunggulan Kompetitif Perusahaan. Jurnal Ilmiah Mahasiswa Akunatnsi Universitas Katolik Widya Mandala Surabaya, 1(2).

Hadjoh, R. A., \& Sukartha, I. M. (2013). Pengaruh Ukuran Perusahaan, Kinerja Keuangan dan Eksposur Media pada Pengungkapan Informasi Lingkungan. E-Jurnal Akuntansi Universitas Udayana, 4(1).

Halim, A., \& Irawan, A. S. (1998). Perspektif Akuntansi Lingkungan, Suatu Tinjauan Teoritis Mengenai Isu Dampak Lingkungan Terhadap Akuntansi. Jurnal Ekonomi Dan Bisnis Indonesia, 13(3).

Handayati, P., \& Rochayatun, S. (2015). The effect of environmental performance and corporate governance mechanism on the corporate social responsibility disclosure. International Journal of Business, Economics and Law, 8(1).

Haniffa, R., \& Cooke, T. E. (2005). The impact of culture and governance on corporate social reporting. Journal of Accounting and Public Policy, 24(5).

Hartono, J. (2007). Teori Portofolio dan Analisis Investasi. Yogyakarta: BPFE. 
Hidayat, M. (2016). Perkembangan Green Accounting dan Penerapannya dalam Menjawab Permasalahan Lingkungan di Indonesia. Jurnal Online Fakultas Ekonomi Universitas Riau, 1(4), 1-10.

Indrayanti, A., Suprasto, H. B., \& Astika, I. B. P. (2017). Pengaruh Kompetensi pada Kinerja Auditor Internal Dengan Motivasi, Komitmen Organisasi dan Ketidakpastian Lingkungan sebagai Pemoderasi di Inspektorat Kabupaten Tabanan. E-Jurnal Ekonomi Dan Bisnis Universitas Udayana, 6(11).

Instanti, S. L. W. (2009). Teori Kontingensi, Sistem Pengendalian Manajemen dan Keluaran Perusahaan: Hasil yang Lalu dan Arah Masa Depan. E-Jurnal Potensio, 18(2).

Ismail, M., \& Simbolon, M. F. D. (2013). Implikasi Akuntansi Lingkungan serta Etika Bisnis Sebagai Faktor Pendukung Keberlangsungan Perusahaan Di Indonesia. E-Jurnal Universitas Sumatera Utara, 1(1).

Keown, A. J. (2004). Manajemen Keuangan. Edisi 9, Jakarta: Indeks

Kusumadilaga, R. (2010). Pengaruh Corporate Social Responsibility Terhadap Nilai Perusahaan Dengan Profitabilitas Sebagai Variabel Moderating Pada Perusahaan Manufaktur Yang Terdaftar Di BEI. Skripsi. Sarjana Jurusan Akuntansi pada Fakultas Ekonomi dan Bisnis Universitas Diponegoro.

Latupono, S. S. (2015). Pengaruh Corporate Social Responsibility terhadap Nilai Perusahaan dengan Good Corporate Governance sebagai Variabel Moderating. E-Journal STIESIA, 4(8).

Limijaya, F. A. (2014). Triple Bottom Line dan Suistainability. Jurnal Fakultas Ekonomi Katolik Parahyangan, 18(1).

Lingga, W., \& Suaryana, I. G. N. A. (2017). Pengaruh Langsung dan Tidak Langsung Kinerja Lingkungan pada Nilai Perusahaan. E-Jurnal Akuntansi Universitas Udayana, 20(2).

Makalew, S. I. Y. (2017). Pengaruh kinerja lingkungan terhadap kinerja keuangan perusahaan dengan pengungkapan informasi lingkungan sebagai variabel mediasi. Skripsi. Sarjana Jurusan Akunatnsi pada Universitas Katolik Widya Mandala, Surabaya.

Meutya. (2008). Menyibak Kepentingan Dibalik Pengungkapan Tanggung Jawab Sosial.

Mobus, J. L. (2005). Mandatory environmental disclosures in a legitimacy theory context. Accounting, Auditing, and Accountability Journal, 18(4). 
Nahda, K., \& Harjito, D. A. (2011). Pengaruh Corporate Social Responsibility Terhadap Nilai Perusahaan Dengan Corporate Governance Sebagai Variabel Moderasi. Jurnal Siasat Bisnis, 15(1).

Nurani, W. (2015). Pengaruh Pengungkapan Corporate Social Resposibility (CSR) terhadap Nilai Perusahaan dengan Kinerja Lingkungan dan Struktur Kepemilikan Modal Asing sebagai Variabel Moderating.

Nursasi, Enggar. (2017). Analisis Pengungkapan Lingkungan Terhadap Kinerja Keuangan dan Kinerja Saham. Jurnal DINAMIKA, 8(1).

Octavia, I. (2012). Pengaruh Pengungkapan Lingkungan Terhadap Nilai Perusahaan Dengan Profitabilitas Sebagai Variabel Moderasi. Skripsi. Sarjana Jurusan Akuntansi pada Fakultas Ekonomi Universitas Indonesia, Jawa Barat.

Pflieger, J. E. (2004). The contribution of life cycle assessment to global sustainability reporting of Organization. Management of Environmental, $16(2)$.

Porter, M., \& Linde, V. der. (1995). Green and Competitive: Ending The Stalemate. Harvard Business Review, 73(5).

Purnomosidhi, B. (2006). Praktik Pengungkapan Modal Intelektual Pada Perusahaan Publik di BEJ. Jurnal Riset Akuntansi Indonesia, 9(1).

Purwanto, A. T. (2000). Pengukuran Kinerja Lingkungan.

Puspaningrum, Y. (2014). Pengaruh Corporate Social Responsibility dan Kepemilikan Manajerial terhadap Nilai Perusahaan dengan Profitabilitas dan Ukuran Perusahaan sebagai Variabel Moderating. Jurnal Profita, 2.

Ramona, S., Afriyanto, \& Yuliza, A. (2017). Pengaruh Corporate Social Responsibilty terhadap Nilai Perusahan dengan Profitabilitas sebagai Variabel Moderating. E-Jurnal Mahasiswa Prodi Akuntansi Universitas Pasir Pengaraian, 3(1).

Retno, D. R., \& Prihatinah, D. (2012). Pengaruh Good Corporate Governance dan Pengungkapan Corporate Social Responsibility Terhadap Nilai Perusahaan (Studi Empiris Pada Perusahaan yang Terdaftar di Bursa Efek Indonesia Periode 2007-2010). Jurnal Nominal, 1(1).

Risa, N., Sulastri, T., \& Pramono, J. (2011). Corporate Social Responsibility Perusahaan Kepada Masyarakat Studi Kasus pada PT Gold Coin Specialities. 
E-Jurnal Riset Akuntansi Dan Komputerisasi Akuntansi, 2(2).

Rosiana, G. A. M. E., Juliarsa, G., \& Sari, M. M. R. (2013). Pengaruh Pengungkapan CSR terhadap Nilai Perusahaan dengan Profitabilitas sebagai Variabel Pemoderasi. E-Jurnal Akuntansi Universitas Udayana, 5(3).

Soerjani, M. A., Rofiq., \& Munir, R. (1987). Lingkungan: Sumberdaya Alam dan Kependudukan. Jakarta: UI-Press.

Sudarma, I. K. G. A. M., \& Darmayanti, N. P. A. (2017). Pengaruh CSR, Kepemilikan Manajerial dan Profitabilitas terhadap Nilai Perusahaan Sektor Pertambangan pada Indeks Kompas 100. E-Jurnal Manajemen Universitas Udayana, 6(4).

Sujoko, \& Soebiantoro, U. (2007). Pengaruh Struktur Kepemilikan Saham, Leverage, Faktor Interen dan Faktor Eksteren terhadap Nilai Perusahan. Jurnal Manajemen Dan Kewirausahaan, 9(1).

Suka, E. A. (2016). Efektivitas Akuntansi Lingkungan dalam Meningkatkan Nilai Perusahaan. Skripsi.

Suranta, S. (2013). Pengaruh Sistem Akuntansi Manajemen dan Gaya Kepemimpinan terhadap Hubungan antara Total Quality Management dengan Kepuasan Kerja pada Perusahaan Go Publik di Bursa Efek Jakarta. Jurnal Akuntansi Universitas Sarjanawiyata Tamansiswa Yogyakarta, 1(1).

Susanti, H. (2017). Penerapan Akuntansi Pertanggungjawaban Sosial Sebagai Bentuk Tanggung Jawab Perusahaan Terhadap Lingkungannya. Jurnal Univesitas Darul Ulum Jombang, 4(2).

Tjahjono, M. E. S. (2013). Pengaruh Kinerja Lingkungan terhadap Nilai Perusahaan dan Kinerja Keuangan. E-Jurnal Ekonomi, 4(1).

Verrecchia, R. E. (1983). Discretionary disclosure. Journal of Accounting and Economics, 5(1).

Wardhana, P. K. (2017). Pengaruh Biaya Lingkungan dan Kinerja Lingkungan dalam Memoderasi Pengaruh Profitabilitas terhadap Nilai Perusahaan. EJurnal Universitas Negeri Surabaya, 6(1).

Yuniasih, N. W., \& Wirakusuma, M. G. (2007). Pengaruh Kinerja Keuangan terhadap nilai perusahaan dengan pengungkapan corporate social responsibility dan good corporate governance sebagai variabel pemoderasi. E-Jurnal Ekonomi Dan Bisnis Universitas Udayana, 4(1), 1-10. 